\title{
The riverbank, the seashore and the wilderness: Miriam, liberation and prophetic witness against empire
}

\begin{tabular}{|c|c|}
\hline $\begin{array}{l}\text { Author: } \\
\text { Allan A. Boesa }\end{array}$ & \\
\hline $\begin{array}{l}\text { Affiliation: } \\
{ }^{1} \text { Department } \\
\text { and Christian } \\
\text { of Theology, } \\
\text { Pretoria, Sout }\end{array}$ & $\begin{array}{l}\text { ff Dogmatics } \\
\text { Ethics, Faculty } \\
\text { niversity of } \\
\text { h Africa }\end{array}$ \\
\hline $\begin{array}{l}\text { Research Proj } \\
\text { Project Leade } \\
\text { Project Numb }\end{array}$ & $\begin{array}{l}\text { ct Registration: } \\
\text { :J. Buitendag (1) } \\
\text { er: } 02402343\end{array}$ \\
\hline $\begin{array}{l}\text { Project Descr } \\
\text { Dr Allan Boes } \\
\text { participating i } \\
\text { project, 'Univ } \\
\text { and Theology } \\
\text { Prof. Dr Johan } \\
\text { Department o } \\
\text { and Christian } \\
\text { Dean, Faculty } \\
\text { University of }\end{array}$ & $\begin{array}{l}\text { ption: } \\
\text { k is } \\
\text { n the research } \\
\text { rsity, Education } \\
\text {, directed by } \\
\text { Buitendag, } \\
\text { f Dogmatics } \\
\text { Ethics and } \\
\text { of Theology, } \\
\text { retoria. }\end{array}$ \\
\hline $\begin{array}{l}\text { Correspondin } \\
\text { Allan Boesak, } \\
\text { boesak@mwe }\end{array}$ & $\begin{array}{l}\text { g author: } \\
\text { b.co.za }\end{array}$ \\
\hline $\begin{array}{l}\text { Dates: } \\
\text { Received: } 15 \\
\text { Accepted: } 15 \\
\text { Published: } 25\end{array}$ & $\begin{array}{l}\text { Mar. } 2017 \\
\text { May } 2017 \\
\text { July } 2017\end{array}$ \\
\hline $\begin{array}{l}\text { How to cite th } \\
\text { Boesak, A.A., } \\
\text { riverbank, the } \\
\text { the wildernes } \\
\text { liberation and } \\
\text { witness again } \\
\text { Teologiese Stc } \\
\text { Theological St } \\
\text { a4547. https:/ } \\
10.4102 / \text { hts.V }\end{array}$ & $\begin{array}{l}\text { is article: } \\
\text { 2017, 'The } \\
\text { seashore and } \\
\text { s: Miriam, } \\
\text { prophetic } \\
\text { t empire', HTS } \\
\text { dies/ } \\
\text { udies 73(4), } \\
\text { /doi.org/ } \\
73 i 4.4547\end{array}$ \\
\hline $\begin{array}{l}\text { Copyright: } \\
\text { (c) 2017. The } \\
\text { Licensee: AOS } \\
\text { is licensed un } \\
\text { Creative Com } \\
\text { Attribution Lic }\end{array}$ & $\begin{array}{l}\text { Iuthors. } \\
\text { IS. This work } \\
\text { der the } \\
\text { nons } \\
\text { ense. }\end{array}$ \\
\hline Read online: & \\
\hline 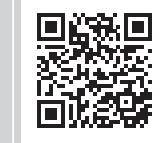 & $\begin{array}{l}\text { Scan this QR } \\
\text { code with your } \\
\text { smart phone or } \\
\text { mobile device } \\
\text { to read online. }\end{array}$ \\
\hline
\end{tabular}

Author:

Affiliation

'Department of Dogmatics of Theology, University of

Research Project Registration: Project Leader: J. Buitendag $\mathbb{0}$ Project Number: 02402343

Project Description participating in the research and Theology', directed by Prof. Dr Johan Buitendag, Department of Dogmatic Dean, Faculty of Theology, University of Pretoria.

Corresponding author: Allan Boesak,

Dates:

Received: 15 Mar. 2017 Accepted: 15 May 2017

How to cite this article: Boesak, A.A., 2017, 'The riverbank, the seashore and witness against empire', HTS oologiese Studies/ Theological Studies 73(4), a4547. https://doi.org/

Copyright: Licensee: AOSIS. This work is licensed under the Creative Commons Attribution License.
This article examines the manner and method of resistance against patriarchal power and privilege. Two types of power are contrasted. One is the violent, war-like and hierarchical power of an empire, and the other is the faithful resistance of Israel's prophets. A further distinction is made between violent male power and non-violent female power. It is argued that Miriam was a prophet of the people and her prophetic witness is an example of the power and outcome of non-violent resistance. Her theology explicitly and specifically praises God not as a warrior. Hers is not a muscular, masculine God whose power seeks to match the power of empire. Her God has a power that through radical love for a slave people and taking sides with the enslaved overcomes the power of the slaveholder. In her theology, Miriam recalls the God of the exodus, who begins the acts of liberation with the women, to whose faithfulness, courage and defiant obedience, the freedom of the people is entrusted. From a feminist perspective it is argued that this style of non-violent, faithful prophetic witness has a greater impact than violent resistance associated with an empire-like power. It is suggested that black liberation theology should adopt this paradigm in its witness of and resistance against oppression.

\section{The women in Exodus}

We first meet Miriam as guardian and protector on the riverbank, then as prophet and leader after the deliverance at the Red Sea and finally as prophetic challenge to power in the wilderness. What Hebrew Bible scholar Phyllis Trible calls the 'Miriamic presence' (Trible 2001:173) becomes the Miriamic tradition, the prophetic tradition of faithful resistance against empire, the early temptation in ancient Israel to imitate the ways of empire and against patriarchal power and privilege. Miriam emerges against the darkness of unimaginable oppression: a darkness pierced only by the light of the fierce, audacious hope held by two women.

The tyranny of the Pharaoh we meet in Exodus 1 leaves no room for misunderstanding. The Egyptian taskmasters aimed to 'bend', 'to wear out anyone's strength', to 'break them down physically', to 'crush' the Israelite slaves. Their goal was not only physical, it was also to 'crush their spirit so as to banish the very wish for liberty' (Keil \& Delitzsch n.d.:422). 'This Pharaoh suggested three means of oppression: the first was forced labour, the second infanticide, [and ] ... the third was mass infanticide' (Keil \& Delitzsch n.d.:422). This despotism, as all despotism, 'knows only two paths - enslavement and murder' (Jacob 1992:22).

Siphrah and Puah, the Hebrew midwives, defy the command of Pharaoh to kill the baby boys even as the Israelite women are on the birth stool. They become the symbol of resistance, standing in for the whole people of Israel. It is not just the people under imperial tyrannical rule who cannot stand tyranny however, John Calvin writes, reflecting not only the political situation in his own time, but building a framework for resistance against such conditions generally. God self 'cannot endure tyrants and [God] listens in empathy to the secret groans of those who live under them' (Calvin 1981; Commentary on Isa 14:7-8).

Elsewhere, Calvin will radicalise this thought considerably. Not only does he tell us that the longing for freedom and justice is 'implanted in us' by God, but also that the cries against oppression are not only heard by God, but 'it is as if God hears [God]self in the cries of the oppressed' (Commentary on the 12 Minor Prophets, Hab 2:11). Note that the cries against oppression are no longer 'secret groans' - the oppressed 'cry out'. And God no longer just 'listens in empathy'. God becomes the poor and oppressed and their cry becomes God's cry. 
Their impatience with tyranny, 'How long?', becomes God's impatience. Their struggles are now God's struggles.

In a sentence that underscores the necessity of endurance and revolutionary patience, Israel will come to need so much in the wilderness as this story will show, Calvin writes that resistance to tyranny does indeed bring risks and unforeseen changes, but 'only a degraded people could prefer the yoke of tyranny to the inconveniences of change' (Commentary on Matt 2:9). Calvin's judgement on those who for some reason or another are afraid to resist tyranny is quite harsh. 'There is no doubt that God has struck with a spirit of cowardice those who, like asses, willingly offer their shoulders for burdens' (Commentary on Is 3:12). Because tyrants do not 'rest their injuries until the wretched people have altogether given up', resistance is inevitable and Calvin finds inspiration for that resistance in the example of the Hebrew midwives who stood up against the Pharaoh (Commentary on Ex 1). All this is in stark relief as we read the story of Siphrah and Puah, and this is the context within which Miriam steps into the exodus story.

\section{On the riverbank}

Moses is born under the dark and menacing cloud of the genocidal cruelty of the king of Egypt. Miriam's mother, Jochebed, takes an extraordinarily risky, and courageous, initiative. She wove a basket, put the baby boy in it, placed it among the reeds close to the riverbank and tasked the young Miriam to stand guard. In these initiatives, there seems to be no expectation that God would directly intervene, and there is no sign of such a promise. And tellingly, there is no male Israelite in sight. In chapter 1 , some scholars point out, God is 'in the background', 'behind the scenes'. But although God is not even mentioned here, this is the exodus story, the story of God and the liberation of the people of Israel, and this God is a God who rises up in resistance against the gods of Egypt, the One who stands with the enslaved, the oppressed and the threatened. That God, not directly spoken of, is nonetheless wondrously present. The women, here and in chapter 1 , need not be reminded. They act in faith, and it is a faith anchored in trust, not in sight.

At the riverbank, Miriam is standing 'at a distance' (New Revised Standard Version [NRSV]). However, Dutch Hebrew Bible scholar Jopie Siebert-Hommes reminds us that the same verb has an additional meaning: 'unattainable', 'far away' (Siebert-Hommes [1994] 2001:69-70). She cites Hebraic scholar Rochus Zuurmond who writes that the word denotes a qualitative, rather than a quantitative separation, and it applies not to Miriam's physical distance as much as to the utter vulnerability of the baby in the basket. 'Lying in the bulrushes, the child is delivered up to death'. In other words, he is as far from help as one could imagine. Zuurmond writes, 'The delicate connotations of qualitative unattainability [of help] are not captured by the phrase "at a distance"'. If there is a sense of 'distance' here, the 'distance' is more the distance from help and safety in the light of the lurking imminence of death (Siebert-Hommes 2001:70, quoting Zuurmond 1976:2511). Siebert-Hommes concludes that the translation 'afar off' captures that concept better. It is important to keep this valuable distinction in mind as the story continues.

But Siebert-Hommes takes this still further and opens up a whole new, and in my view, crucial, understanding of the verb used in this verse. The Hebrew word used here has two meanings, she argues: (1) 'to take one's stand' and (2) 'to stand one's ground'. As in the 'striking example' of the use of the same word in Exodus 14:13 where Moses urges the people to 'stand firm' as they were pushed against the Red Sea by Pharaoh's armies, Miriam is standing and waiting in anticipation of Yahweh's wondrous deeds. In this sense, 'it seems legitimate to suggest that Miriam stood there in order to see how God would deal with the matter'. But Miriam is also 'standing her ground' (Siebert-Hommes [1994] 2001:6970; cf. Brown Douglas 2015). ${ }^{1}$

This is important, I think, for two reasons. Firstly, it shifts the emphasis from the question of 'distance' to Miriam herself. Secondly, in this passage unbearably crowded with risks and uncertainties, it offers perspective on Miriam's frame of mind. In the first meaning, I suggest, Miriam can be understood to wait in faith upon Yahweh's intervention, clearly aware of her own limitations under the circumstances. What if it were not Pharaoh's daughter, but instead a search party of the palace guard, or for that matter any Egyptian acting in blind obedience to the Pharaoh's killing instructions, who came to the river in the course of executing the Pharaoh's command and discovered the child? And what if the Pharaoh's daughter were of one mind with her father, sharing his fear and the whipped-up national paranoia about the Israelite numbers as a threat to the security of the Egyptian state, and thought it her duty to call the guards?

Moreover, even when Miriam saw that it was Pharaoh's daughter, there could have been no rational expectation in Miriam's mind of a 'motherly' response from one who, at that crucial moment on the riverbank, was in first and foremost a representative of the Egyptian empire and everything that frightening reality represents. She is, after all, Pharaoh's daughter, as the text keeps reminding us. Thus understood, waiting upon the LORD, but still waiting not in passive timidity but with vigilant alertness becomes an attitude of faith and trust only affirming Miriam's spiritual strength. It means waiting upon Yahweh's intervention to create the opportunity for her to act as decisively as she was ready for.

1.This is of course not to be confused with the pernicious, and racially laden "standyour-ground' laws enacted and practised in the US, becoming especially notorious
with the killing of a young African American man, Trayvon Martin, by self-appointed with the killing of a young African American man, Trayvon Martin, by self-appointed
'neighbourhood watchman' George Zimmermann, on February 26, 2012, in Sanford, 'neighbourhood watchman' George Zimmermann, on February 26, 2012, in Sanford,
Florida. Besides its odious legal and racist aspects, 'stand-your-ground' has theological implications as well. White Americans, writes Kelly Brown Douglas, have 'Stand-your-Ground' rights, as rights granted them through white privilege and white supremacy. These rights are not only racially exclusivist, they are also 'divine', since 'whiteness is the gateway to God'. Anglo-Saxon exceptionalism is virtually projected onto the sacred cosmos, and it is with the construction of whiteness as 'cherished property' that a stand-your-ground culture is finally born. A stand-your'cherished property' that a stand-your-ground culture is finally born. A stand-yourground culture is nothing other' than the enactment of whiteness as cherished property. 'It is the culture that protects the supremacy of whiteness.' It ensures that 'nothing nonwhite intrudes on white space'. In that sense, Zimmermann, who armed with a gun, was actually stalking Trayvon Martin who was unarmed, killin him, then claiming self-defence: he was only 'standing his ground', was expressing the culture that protects the supremacy of whiteness. In light of this, Brown Douglas (2015) asks, 'Could Trayvon Martin have stood his ground on that sidewalk?' Clearly, what we are discussing here with regard to Miriam is an entirely different matter. 
When she does act, her quick-witted response to the presence of Pharaoh's daughter suggests not only spiritual maturity, but political savvy as well.

Even in Exodus 14 though, the text does not encourage passivity, but rather active, faithful action. Fretheim (1991:156) sees this also. The people are to 'stand firm' - that means to be 'at the ready'. Yet they are not to fight, for it is 'God [who] is about to deliver Israel from the Egyptians forever'. The point is that this is not a military battle - it is all God's wondrous power at work here. The people are to 'keep still'. This is not a word asking that the people 'not move a muscle'. It is not a call for passivity, 'it is a word calling for silence' (Fretheim 1991:157). They should stop moaning in fear and trembling of what Pharaoh might do.

When Moses tells the people that Yahweh will fight their battles for them, there comes a surprising response. The reader is 'not prepared for it' writes Fretheim, and many scholars believe it rightly belongs after verse 12 (pp. 157-158). But I would suggest that it belongs perfectly well here, and is in tune with the emphasis on an activist waiting the verb wants to convey. It is quite possible that Moses himself was not prepared for God's impatient response either. The sentence is emphatic, and it is as if God does not want any misunderstandings here: Yahweh will work, but the people must be ready to actively embrace it. 'Why do you cry out to me? Tell the Israelites to go forward!' (v. 15). To where? Into where there is nowhere else to go: the sea! In this text, waiting upon the LORD to intervene is not despondently sitting down, limply waiting for something to happen. Yahweh acts as the people are ready to move forward in faith and in the firm expectation that deliverance is unfolding. Accordingly, if Miriam is waiting in anticipation, it is a tense anticipation, a coiled readiness to act the moment God creates the opportunity. She knows, unerringly, that this God, the God of the birth chamber, will not stop until the forces of oppression and enslavement are defeated.

In any event, and no matter how we read this, the NRSV's translation of Miriam 'standing at a distance' gives an impression not completely reflective of the text. If the situation should develop into something dangerous and threatening to the baby in the basket in the sense that Zuurmond's reading suggests, Miriam's 'standing her ground' means exactly that. It depicts a readiness to act, a commitment that whatever happens, she would not run away, leaving Moses on his own. She was determined, come what may, to find a way to intervene to defend the baby's life, and that is precisely what she does. It also means, quite obviously, that she was not going to hide, or remain 'at a distance' even if that would be safest and a quite defensible action, seeing the odds. She is ready to reveal herself as the one associated with the child (which is, again, exactly what she does), and who knows what the consequences then might have been?

It is the firmness of her resolve in the face of the uncertainty from all sides that makes this young woman so remarkable.
With or without divine intervention, Miriam was by no means sure what would happen to her. What stands out here is her readiness to stand her ground and face whatever danger may befall her. If something happened to the child, it would not be for lack of courage or action on her part. Under these stressful circumstances, the way she sums up the situation, presents herself and her ready-made plan to the Pharaoh's daughter make for a convincing picture of intellectual dexterity, moral courage and extraordinary commitment. It is prophetic engagement of empire, no less courageous and faithful than the actions of the midwives. So Miriam stands firm, and firmly, in the prophetic tradition begun by Siphrah and Puah.

\section{At the seashore}

When the people of Israel walked through the sea 'on dry land', leaving the Egyptian armies 'dead on the seashore' and the mighty empire for all intents and purposes defeated (14:30), Miriam the prophet took a tambourine in her hand, opened her mouth in song and led the people in a dance of praise. This song represents the oldest extant writing concerning the exodus, and is the oldest poem in the Hebrew Bible. There is, of course, some difference of opinion among the scholars, but Benno Jacob, speaking of the poem as 'the song of Moses', is clear: 'The poem reflected the mood of a recent experience' (the exodus) and it is 'older than the song of Deborah or the Psalms' (Jacob 1992:434).

Traditionally, male commentators, John Calvin, Benno Jacob and some modern exegetes such as Millard C. Lind (1980:46ff) among them, accept the song as originally from Moses. Whereas the poem proper is the Song of Moses, Jacob thinks, verses 20 and 21, where Miriam sings, 'dealt with the musical rendition of the song ... Miriam with timbrel in hand, leading the women', but only the women (Jacob 1992:423) Calvin, too, cannot imagine 'women taking the lead over men' (Commentary on Ex 15:20). Here Miriam is decidedly secondary, reduced from prophet to choir leader. Miriam may have been so 'enthusiastic' about what she had heard [Moses say] that she led the women in repetition and for that she changed Moses' 'I will sing' to 'We will sing' (Jacob 1992:423). But why allow Miriam the power to change Moses' words to fit the occasion she has devised, instead of acknowledging her the power of original authorship? As many have pointed out, it is more reasonable to accept that the shorter version is original, and the longer version an embellishment of that original.

Drorah O'Donnell Setel, however, articulating a growing consensus (O'Donnell Setel 1998; Phyllis Trible (2001:169173) and J. Gerald Jansen (2001:187-199) as well as Fretheim (1991:161), among many others, call it the 'Song of Miriam'. Miriam's version (vv. 20-21) is the shorter and older than the longer version (vv. 1-19) (O'Donnell Setel 1998:35, my emphasis). John Durham (1987:205-210), admitting that this is disputed, argues that ultimately 'it does not matter'. But it clearly does matter because it raises quite pertinently the question of how the story of the exodus rooted in the faith 
and actions of women becomes a story of patriarchal power, with males only having privileged access to a patriarchal God whose appointed agents they become:

The fact that this citation has been preserved despite later perspectives that augment the significance of Moses while diminishing that of his sister has led scholars to believe that the work was indeed originally preserved as her creation. (O'Donnel Setel 1998:35)

Richard Elliot Friedman, like O'Donnell Setel, suffers no uncertainty on both questions: that of the authorship of Miriam and the age of the hymn: 'This poem, known as the Song of the Sea (or the Song of Miriam) is an independent, possibly the oldest composition in the Hebrew Bible' (2003:144).

\section{A song of war?}

The original song is in vv. 20, 21, whose words are taken up again in vv. 1 and 2, and are now laid in the mouth of Moses. Does it matter that as from verse 3 the song becomes an unabashed military song? It matters a great deal, I think. Millard C. Lind considers that it is an 'adjustment' such as is made in the song of Deborah: 'It is an adjustment also made by Moses after the exodus by his acceptance of the military role of Joshua' (Lind 1980:76). Lind sees this adjustment occurring in Exodus 17:8-16, but in reality it happens already in Exodus 15:3. The argument holds here, correctly, however, for Lind is right: essentially ' [such an adjustment] is a threat against the Yahwist tradition, the entrenchment of a secular power that would use religion to achieve its own ends' (Lind 1980:76). The 'ends' here, in my view, are the imitation within Israel of the ways of empire, claiming Yahweh's consent to, and approval of military engagements where the glory is no longer Yahweh's alone, but now shared by Yahweh and the military leader, the king.

For the first time, Yahweh is praised as military leader, quite specifically a 'man of war'. The tone changes dramatically, as it equally dramatically changes the framework in which this song is now sung and meant to be read. With the praise of Yahweh as 'warrior', the language becomes warlike and more belligerent; war as war is glorified and Yahweh becomes the mere instrument through whose power the war is waged. The masculine bombast, the nationalistic belligerence and the stringent muscularity of the theology in the poem are striking, and strikingly different from the Song of Miriam. Emphatically too, this warlike language changes the reality of the exodus story, from a history of God's glorious intervention to a glorification of war and conquest. And it is this moment, in the conflation of the miraculous delivery from Egypt with the myth of the blitzkrieg in and conquest of Canaan and the glories of a Jerusalem not yet reality, but here foreseen, that completely changes the character of the exodus story as it is taken from the women and placed in the hands of the men. In fact, it seems to me that here the exodus story ends, with the women, and the story of conquest begins, with the men.

Millard Lind seems to take no cognisance of the fact that the 'military' character of the poem starts with v. 3, after the appropriation of the Song of Miriam and at the 'take-over' of the patriarchal narrative with Moses at its centre. He is emphatic: 'There is no question but that the exercise of military power is the theme of this poem' (Lind 1980:49). Even though Lind, seeing his pacifist reading of these narratives, insists that 'it is described as a battle, but not in the conventional [i.e. military] sense' (p. 49), surprisingly though, O'Donnel Setel also sees the song as a warrior song. There is, she argues, a familiarity in the Hebrew Bible with the image of female warriors. 'Beside the fact that there is no evidence of women's participation in battle, modern cultural prejudices should not prevent us from considering that possibility' (O’Donnel Setel 1998:35).

But our 'modern cultural prejudices' hardly come into play here. In liberation wars in the Global South quests for freedom women have long played significant roles in violent struggle. The armed forces of the American empire fully accept women, and have for many years, and recently made that inclusion more comprehensive. Women are now fully recognised as soldiers and combatants at the same level as men. Whether that is a strong argument for the equality of women in modern society I doubt sincerely. South Africans have words for such misguided desires for equality with men that do not take into account that it is the men who are the ultimate beneficiaries of this stance, not women. It is what a young man from the black townships, in a series of conversations on South Africa's reconciliation process I had led in 2011, tellingly called 'bureaucratised feminism'. Psychologist Cheryl Potgieter and theologian Sarojini Nadar, also both South African, in an even better formulation, called this phenomenon 'formenism':

Formenism, like masculinism, subscribes to the belief in the inherent superiority of men over women, but unlike masculinism it is not an ideology developed and sustained by men, but an ideology designed, constructed, and sustained by women. Like its phonetics suggests, this is a concept for me - that is to say, men are the chief beneficiaries of the hierarchical social positioning that it advocates. (Potgieter \& Nadar 2000:143)

These are women placed or allowed in positions of influence and sometimes considerable power but only after they have completely embraced the kind of masculinity that in turn embraces aggression, violence and war, and the carelessness that comes with it that blocks all reason and compassion.

Politically we have seen this in the politics of women such as Indira Gandhi and her suppression of dissent in India in the late 1970s, with Margaret Thatcher of Britain and Madeleine Albright, US Secretary of State in the Clinton White House, and more recently with Condaleezza Rice in the George W. Bush administration, Hilary Clinton as US Secretary of State under Barack Obama and as presidential candidate, and Samantha Power, Obama's ambassador to the United Nations. They are women, and they claim to represent feminism, but their politics is the kind that leaves the patriarchal systems of empire, and the empire itself, completely intact. They exercise power for the benefit of empire, serving the patriarchal agenda and strengthening patriarchal power instead of challenging and subverting it. 
They are for men, not feminist; theirs is not feminism but formenism. ${ }^{2}$

O'Donnell Setel likens the Song of Miriam to the Song of Deborah (Jdg 5) and as such it 'challenges sexual stereotypes about women in ancient Israel', because 'it conveys an image of women as singers of war songs' (p. 35). Again, it is strongly doubtful that this kind of equality with men - in belligerence, the despicable politics of war and the inevitable crimes of war, the mindless annihilation of the vulnerable of the world, the thousands upon thousands of women and children, and the utterly senseless destruction of the earth in every place America has been waging its endless imperial wars - is the kind of equality our world is in need of.

These arguments aside however, the Song of Miriam is not a battle song as Setel insists. As Exodus 14 makes clear, this was no military battle; it was divine intervention on behalf of Israel. The point the Song of Miriam makes is exactly this: the vast military power of the empire is not able to withstand the power of God exercised on behalf of God's powerless people. The assurance that 'Yahweh will fight your battles' means that Israel does not take up arms.

Miriam is not a fighter for the dubious right of women to be equal to men in violence and killing, the spilling of blood and the destruction of life, and in the case of the US Empire, in the expansion of neo-liberal capitalism, US militarism, all under the sanctifying power of American exceptionalism. Miriam is not a warrior revelling in the glorification of the might of empire, but a prophet in resistance to empire. The text explicitly calls Miriam a prophet, and that is what she is. ${ }^{3}$ She is the first to contrast the power of Israel's prophetic faithfulness with the Empire's violent power, a conviction firmly embraced in Israel's prophetic tradition as we hear from the lips of Elisha as Eljiah is taken up in the chariot of fire (2 Ki 2:12).

In biblical Israel, the mark of greatness was not superiority in war and domination in imitation of empire. It was instead the imitation of the power of Yahweh: liberation from slavery, steadfast mercy and love, and justice done to the vulnerable, the widow, the stranger and the orphan. Indeed: Israel's very greatness was in preserving the presence of faithful prophetic witness, proclaiming this God, over against the gods of 'the nations'. As Elisha watches Elijah ascending on the 'chariot of fire and the horses of fire', Elisha cries out, 'Father! Father! The chariots of Israel and its horsemen!' (2 Ki 2:12). Other ancient texts read 'Woe! Woe!', appropriate to the deep sense of mourning the loss of the heart of Israel's life. Israel's 'weapons' were not chariots and horses and horsemen with their bows and swords and spears is what Elisha means to

2.I thank Elna Boesak who alerted me to this argument and used to such great effect in her own work. See her unpublished PhD dissertation, Channeling Justice, Feminist Exploration of North American Televangelism in a South African Constitutional Democracy, University of KwaZulu-Natal, 2016.

3.See also Jost (2001:74), who makes the point that it would be incorrect to call Miriam simply 'a singer'. She is also emphatically one who intervened in political affairs. Jost quotes Hermann Speckermann (1982): True prophecy in Israel and affairs. Jost quotes Hermann Speckermann (1982): True prophecy in Israel and
Judah always attended something other than the good will of the king and for that reason it was well armed against any attempt to force it into line (p. 296). say, but rather the faithful, courageous prophetic presence personified by Eljiah. Not military strength, but prophetic power. Not the threat of intimidation and the destruction of violence, but prophetic faithfulness.

The solemn warnings in Deuteronomy 17 against royal abuse have as one of the very first: '[The king] shall not take the people back to Egypt'. 'Taking the people back to Egypt' can only mean taking them back to the deadly imitation of the super power, to the state of mindless enslavement, to before the liberation, away from the prophetic presence, to the other side of those 'blood-red waters' (Boesak 2004:9-10).

Here, at the very dawn of Israel's birth as a free nation, comes the first and foundational confession about who Israel's God is. This God is not only in opposition to the gods of Egypt whom the divine Pharaoh represents and symbolises, but Yahweh is indeed the total opposite of the gods of the empire. Where Egypt depended upon military strength and weapons, Israel trusted in the prophetic presence, the prophetic word and the hesed of God (see also Jacob 1992:411).

'This is Israel's first song which celebrated [Yahweh] and [Yahweh's] wondrous deeds exclusively' (Jacob 1992:411). This is not a song praising the glory of war, Jacob goes on to say:

This song sprang from the experience of Yahweh as judge and helper; therefore, it has been elevated to the crown of all poetry. It awakened only lofty feelings, not bitterness; as divine rather than human victory was celebrated. It did not combine praise of God and a treacherous murder in the same breath, as the song of Deborah. Israel had not yet reached that stage of nationalism which could have celebrated murder as heroism. It believed that 'Mine is vengeance'. [Yahweh] is a God of vengeance, a God from whom revenge emanates. (p. 414, [author's own italics])

Ironically, Jacob can only say this of the original song sung by Miriam. The very first words out of the mouth of Moses nullify this otherwise accurate description. The Moses of 15:4ff. seems to be a far cry from the Moses of 14:13 who knew that if Israel would only 'stand firm ... Yahweh will fight for you'.

Read thus, the Song of Miriam, in contrast with the Song of Moses, celebrates what Martin Luther King Jr. understood so well in reading this text, as 'a great moment' in Israel's history, 'a joyous daybreak that had come to end the long night of their captivity'. But here is King's ([1963] 1981) important insight:

The meaning of this story is not found in the drowning of Egyptian soldiers, for no one should rejoice at the death or defeat of a human being. Rather, this story symbolizes the death of evil and of inhuman oppression and unjust exploitation. (p. 79)

And for King, 'evil' is not something esoteric, the result of primitive thinking or the stuff of overwrought imaginations:

Within the wide arena of everyday life, we see evil in all of its ugly dimensions. We see it expressed in tragic lust and inordinate selfishness. We see it in high places where men [sic] are willing to sacrifice truth on the altars of their self-interest. We see it in 
imperialistic nations crushing other people with the battering rams of social injustice. We see it clothed in the garments of calamitous wars which leave men [sic] and nations morally and physically bankrupt. (King, [1963] 1981:78; see also Allan Boesak [1987] 2015:117; Boesak 2015:129-130)

For black liberation theology, this issue raises at least two questions: Firstly, would the long and intense debates about violence and nonviolence in black liberation theology have been different if we had understood that in proclaiming the exodus tradition we are not calling upon Moses' God as 'a man of war' who blesses our violence and military might but on Miriam's God as the One who parts the waters and lets us see the death of evil upon the seashore? The One, as Hannah sings, who 'breaks the bow of the mighty' and 'cuts off the wicked in darkness, for not by might shall one prevail' (I Sm 2:9), and who, in Mary's Song, will 'throw down the powerful from their thrones'? (Lk 1:52). Secondly, and perhaps even more crucially, would the image of God in black liberation theology have been entirely different - not only less violent, but also less patriarchal, more feminine, less exclusivist?

Jacob reads the song as a celebration of contrasts. This song is not about Israel's military strength, military tactics or courage in battle. These events were the works of God's hands. Not arms and horses and chariots, but the elements of nature were God's tools: 'But there was a difference. God was not in the water [roiling in and with it] but above it [in control of it]'. The divine breath had parted the waters, consumed the foe like stubble. 'This presented a contrast to Pharaoh's boast which emphasized, "I will pursue"; "my sword"; "my hand." The enemy's destruction was paralleled by God's gentle leadership of Israel' (Jacob 1992:418, [italics original]).

Miriam's song also contrasted the disdain and hatred of the Pharaoh for his slaves with the love God has for God's enslaved people expressed in God's judgement of the slaveholder, 'for [God] favored the oppressed and was their redeemer' (p. 418). This thought, argues Jacob, is the focal point of the entire poem and it is also its 'ultimate lesson': firstly, that Israel's God is a God who sides with the oppressed; and secondly, that Pharaoh's might was established upon chariots and riders, for he was a human king who ruled by military force. Israel's kings felt no need for such display of power till Solomon who imitated the Egyptians Jacob argues:

God's might was presented in contrast, so they were immediately destroyed by [God] who ruled only through the power of [God's] name. [God is] the One who has no pleasure in the strength of horses. (Ps 147:10; p. 419)

The song is not only a song of celebration and contrast. It is also a song of protest. It protested the teaching of the powerful, who claimed that God was always on the side of the strongest armies. 'There were mightier forces [than the power of empires] and God is showing that here' (Jacob 1992:419).

\section{Prophet of the people}

Jacob makes the point that Miriam in verses 20 and 21 'turns the song into a congregational hymn', meaning that whereas
Moses had done this as an individual, on Miriam's lips it is a song of praise and celebration for the whole people. Jacob makes it sound like a kind of accusation, presumably because of the radical inclusion of all the people, not just the men, and the implied leadership position it gives Miriam, also over the men. But in doing this Miriam proves herself to be a prophet of God from among the people, insisting on the inclusion of men and women in the glorification and hence the ownership of the mighty acts of God, thereby owning their agency in their liberation, as did Siphrah and Puah.

Phyllis Trible points out that the text reads that Miriam, with tambourine in hand, sang responsively to 'them'. 'Yet, the Hebrew pronoun "them" is masculine, not feminine, gender, yielding an ambiguous referent'. The conclusion is not farfetched: that under the leadership of Miriam, the ritual includes all the people, 'though the major participants were women' (2001:171). Already here Miriam's prophetic leadership is qualitatively different from that of Moses. It is radically inclusive.

What happens here is quite radical, in my view. And even here she is setting the dangerous precedent, most importantly for women's prophetic leadership, but also for women's equal participation in ritual and worship, in claiming the wondrous delivery from Egypt for all the people. Moses claims individual ownership; Miriam opens ownership of the praise for Yahweh to the whole people. Moses' song is in praise of an individual standing in for the whole. Miriam's song is a celebration of the collective thanksgiving, praise and worship of the God who is the Savior of all the people. Miriam's theology is one that does not abide mediators and 'middle men': she stands, and brings the people with her, directly before the One who hears, knows, sees and rescues. There is a radical inclusivity of worship at work here, and a radical overturning of the patriarchal paradigm. It is also a radical embracing of the responsibilities that come with freedom. Miriam is the people's prophet.

Miriam's is a theology that explicitly praises God not as a warrior. Hers is not a muscular, masculine God whose power seeks to match the power of Empire. Her God has a power that through radical love for a slave people and taking sides with the enslaved overcomes the power of the slaveholder. In doing this, Miriam recalls the God of the exodus, who begins the acts of liberation with the women, to whose faithfulness, courage and defiant obedience the freedom of the people are entrusted.

Miriam the prophet of the people - women and men following her in praising the glory of Yahweh - sings a song that will be picked up by Hannah: 'Not by might shall one prevail' (I Sm 2:9). It is a song that praises the One who delivers by raising up the poor 'from the dust of the earth', and overcoming not only the violence of the powerful and the wicked who 'shall be cut off in darkness', but also the desire for violence on the part of those whose trust is in God. It is the God Mary's 'soul will magnify' in the Magnificat as she calls to remember the God who was Israel's helper in the 
liberation from Egypt, in the birth chamber and at the parting of the waters; the One who 'scatters the proud in the thoughts of their hearts', and who will 'fill the hungry with good things', sending the rich away with empty hands (Lk 1:46-55). And would this New Testament Miriam in recalling the promises of Yahweh to the 'descendants of Abraham' not count Miriam as prominent among them? And it is the prophet of the people that Miriam will emerge once again in the wilderness.

\section{In the wilderness}

The wilderness becomes the place of the final revelation of the power of Miriam's prophetic calling. Trible vividly speaks of the 'wilds of the wilderness' (2001:173). It is more than just a place of wandering. The uncertainties, complaints, confusions and conflict make this a 'wild' place. Everything, including the deity, becomes ambivalent. The people rebel and this causes great shifts in the narrative, but there is more at hand:

Entangled in the wilderness multiple layers of tradition defy source analysis and internal coherence to become much like the chaos they report. The task of the interpreter is to discern Miriam's story amid the muddle. (Trible 2001:173)

In this contention, indeed rebellion, Miriam is central, and crucial, as we shall see.

Most commentaries read the series of rebellions as a lack of faith in the promises of Yahweh which lays a heavy burden on the leadership of Moses. The blame is on the recalcitrant people. Naomi Graetz, appropriately, urges us to read Miriam's role in the wilderness within the context of recurring rebellion against Moses, a 'people's rebellion' she calls it (Graetz 2001:231-237). It begins in Numbers 11. Ominously, the chapter opens with the reference to 'Taberah', which means 'burning'. The fire that destroys only the periphery of the camp is Yahweh's inflamed response to the people's first complaints. That fire is only the beginning. The growing, rebellious restlessness reveals as much about the people as it does about Moses and the God Moses calls upon.

But what Graetz calls a 'people's rebellion', Maarsingh sees as the rebelliousness of disgruntled groups, he identifies as 'rabble', a 'mixed company' of people (not Israelites?) who came along with the Israelites when they left Egypt (Maarsingh 1987:38). Philip J. Budd thinks that the 'degree of contempt' that may be in the word 'riff-raff' indicates those among the Israelites 'governed not by powers of discrimination and insight, but by sensual appetite' (Budd 1984:127). At this point, the 'anger' of the LORD does not yet claim human lives although coming perilously close, and the people are now put on alert that complaining against Moses carries a cost.

It is only later that the text discloses that the complaints are about food, to be precise, the lack of meat, and for Maarsingh, it is among the 'rabble' that the demand for food begins and spreads to the Israelites (Maarsingh 1987:38, 39). This 'mixed group' may be the rabble here, but by the time the rebellion reaches its peak the people will all be rebellious rabble in Moses' angry eyes ( $\mathrm{Nm}$ 20:10). At this point, the pretext is the boring menu of manna every day that makes them long for the plenty of Egypt. Earlier, they were somewhat vaguely longing for 'the flesh pots of Egypt' (Ex 16:3). Now, in their heightened agitation, the abundance and variety of Egypt's menu is detailed (Nm 11:4-6).

Moses' response is intense and deeply personalised as he takes his plight to God. He uses words like 'onrush', 'pressure', 'attack'. The Vulgate repeats his 'Why?' three times (Maarsingh 1987:39). There are immediate consequences: (1) Moses' realisation of the difficulties of sole, highly personalised leadership; (2) God's solution: the sharing of responsibility for governance by the appointment of 70 elders. So perhaps even though the complaint is ostensibly about food, Moses' political instincts tell him that there might be more just below the surface. The institution of the elders is a device for the sharing of responsibility for governance. However, it soon becomes clear that sharing of responsibility does not mean sharing of power. The power seems to remain wholly in Moses' hands. What Moses and God propose and implement is not transformation of leadership, it is piecemeal reform.

Almost immediately the limitations of Moses' reformed style of leadership are exposed. It remains what one could call benevolent prophetic dictatorship: the elders did not really 'share' power with Moses; Moses' authority remained unchallenged. They were given some of the spirit 'that was upon Moses' (11:25). In reality, however, that was a top-down arrangement, not an unreserved gifting, seemingly in Moses' control, a spiritual 'trickle-down' act of limited power and hence limited effect: the elders began to prophesy, and then they stopped. 'They did not do so again'.

However, two 'rogue' prophets who 'remained in the camp' emerge, Eldad and Medad. Is it in rebellion against the severe limitation of the 'democratisation' of leadership - only the 70 and a still unchallengeable Moses? Or is it in support of Moses? When the elders 'stopped' prophesying (we are not told why), these two prophesy. They did so because 'the spirit rested on them' (v. 26). The text does not disclose the contents and target audience of their prophecies. Enough people hear them though and news of this extraordinary event spreads quickly. Not surprisingly Joshua, from the circle of Moses' 'chosen men' (Maarsingh 1987:42), already at a young age Moses' protégé, in total support of Moses' leadership, and possibly seeing his chances of taking over the leadership threatened by this bold act, together with another unidentified 'young man' (already part of Joshua's 'transition team'?) 'ran' to complain to Moses.

Moses, however, sees their concern for what it is: 'Are you jealous for my sake?' (11:29). Instead of admonishing Eldad and Medad, Moses utters the surprising, and still inspiring words, 'Would that all the LORD's people were prophets, and that the LORD would put his spirit on them!' One cannot 
really imagine this to be a corrective on Yahweh's decision that Moses should choose only 70 elders on whom 'some' of his prophetic and leadership spirit would rest, while Moses himself would have wanted what we today would call 'full, participatory democracy'.

Clearly, Moses saw no danger in these men also having received the gift of prophecy. Perhaps Moses thought that their concerns were about personal ambition, not reflecting the will of the people. Or was the deciding factor that they were male? For them, there is no rebuke and no punishment. Not for the act of prophecy, nor for the fact that they apparently ignored the command for all the men to gather at the tent: they 'remained in the camp' - with the women. Perhaps Moses did not think that a prophecy, whatever its content, could have significant impact on the situation because the hearers were only women who had no meaningful say in matters of governance anyway.

Perhaps their prophecy was a prophecy in Moses' favour, upholding his leadership as a gift from God to Israel. As such their gift would only help Moses, already struggling to manage a whole people now in rebellion, and would help secure some much needed support and legitimation from the governed. As such also, it could constitute a threat only to Joshua's hopes of leadership, because who knows whether the people, moved by the bold act of prophecy given wholly to Moses and only partially to the elders, would come to see not Joshua, but Eldad or Medad as the natural successors to Moses.

The fact that out of the whole camp only two very selfinterested men raised a complaint may perhaps also mean that the people were indeed ready for less authoritarian rule, a nascent yearning for the egalitarian community Israel would become before the disastrous longing for a king in order to be 'like the other nations' (I Sm 8). If it is, it is a yearning that will return more forcefully in chapter 16 .

\section{'And Miriam spoke'}

'Has the LORD only spoken to Moses? Has he not spoken also through us?' (Nm 12:2). Two sentences of seven words each are about to shake the world of the trekkers through the wilderness. Miriam's speaking 'against Moses', so we recall Graetz's reminder, occurs within the broader context of the people's rebellion, or better: the recurring, and intensifying rebellions of which we are told in Numbers 11, 12, 14, 16 and 20 , beginning with the grumblings about food. Then follow the independent prophecies of Eldad and Medad, the response of Moses and Miriam's question (Nm 11, 12). In chapter 14 it is the people's fearful response to the spies' report that becomes the issue. Here, for the first time, the people are explicit: not only do they want to return to Egypt, they want a new leader. 'Let us' (not God) 'choose a captain' (14:4). God wants 'to strike the people with pestilence'. Here Moses intervenes, and God forgives, but not totally (14:13-25).

Chapter 16 tells of a revolt with strong priestly undertones led by Korah, Dathan and Abiram, and this is more serious, representing a rebellion from different groups, some of them from the 'elite' in Israel, 'leaders of the congregation, chosen from the assembly, well-known men' (16:2). 'You have gone too far! All the congregation are holy, everyone of them, and the LORD is among them. So why then do you exalt yourselves above the assembly of the LORD?' This call for egalitarian inclusivity proves too much. Again God strikes on behalf of Moses. 'The earth opened its mouth and swallowed them up, along with their households - everyone who belonged to Korah and all their goods' (v. 32).

But a rebellion on this scale had to be dealt with more thoroughly, and this God is nothing if not thorough. Not only Moses, but this time Aaron too would be secured in his priestly authority. 'And fire came out from the LORD and consumed the two hundred fifty men offering the incense' (v. 35). This is on top of those who had already perished. As 'the whole congregation' join the rebellion it goes beyond a quarrel over priestly functions and privileges: 'You have killed the people of the LORD' (v. 41). Through it all, Moses' control, albeit with God's aid - God strikes the people with a plague - remains intact, until chapter 20. Trible's description of these events as 'chaotic' is no hyperbole. But it is here, however, with Miriam's speaking, where everything changes.

Budd (1984:135, 138) suggests that 'essentially, Miriam represents those who speak against the representatives of Mosaic authority. This and nothing more is the point of the story'. Miriam's 'suitability as opponent' in the story lies 'simply' in the fact that she is no more than:

a leader figure from the past. Her 'prophetic' connections were valuable because they showed that even those who claimed such inspiration had no right to speak against Moses. There is a uniqueness and supremacy about Mosaic revelation which must be recognized and acknowledged by all. (Budd 1984:135)

Budd's comment on this matter does two things that should give us pause. Firstly, he places Miriam's prophetic role in inverted commas, thereby placing the authenticity of her prophetic action at the seashore in doubt. Was Miriam a pretender, an opportunist now to be finally exposed and dealt with? Second, even if granted a role at the seashore, she is a 'leader figure from the past'. Whatever she might have been at the seashore is over. The new leadership is male, and emphatically so. Miriam, groping for past glory, and those for whom she speaks have failed to 'move on'. But this proves the point so forcefully made by Cheryl Exum that because biblical literature was produced by and for an androcentric community, women in the stories are 'male constructs', they 'serve androcentric interests'. Where women are concerned, one must be suspicious of the motives of male narrators (Exum 2001:79). The duty of the interpreter is to ask why women are allowed to play important roles in the story.

While I do not think that particular suspicion applies to the role of the midwives in Exodus 1, as Exum argues, I do think it is applicable here, not just in the story but in the commentary as well. As I read Budd, Miriam was 'allowed' to play the 'prophetic' role at the seashore, in order to later show the 
absolute 'supremacy' of Mosaic leadership. The role is important only insofar as it serves as a tool in the androcentric narrative, to be used as example of what will happen to those who dare to challenge that authority. That Miriam was the example chosen means that the issue was not just about the 'uniqueness and supremacy' of Mosaic leadership and authority as Budd argues. It was about the uniqueness and supremacy of patriarchal leadership and authority, here set in stone not just for Moses, but for the generations to come. The author is killing two birds with one stone, so to speak, making the matter of patriarchal supremacy, and its untouchability, not merely coincidental, but systemic. In dealing so emphatically with Miriam, however, the narrator also decisively deals with the image of God Miriam has held up at the seashore.

Again the narrator provides us with a pretext: the Cushite woman that Moses married. Mentioned only once, she disappears from the story. Within this broader context, the matter of the Cushite woman functions more as added confusion to the text than providing any real reason for what occurs. Because we know nothing specific, or more, about this woman, 'we can only speculate' (Trible 2001:175).

It seems we have to turn to the women to gain greater clarity on the issue. With accurate hermeneutical suspicion, Trible (2001:175) and Graetz (2001:232-233) raise important questions around the issue: Is this a question of racism, or perhaps ritual cleanliness? Why does the narrator set woman against woman? Why does Moses remain silent when accused by Miriam and Aaron? Why did God [have to] defend Moses' honour in such a drastic way?

In any case, the pretext cannot be sustained and crumbles before the real question Miriam raises: that of prophetic authority. Miriam 'speaks' and asks not only how Moses speaks but also whether Yahweh speaks, if Yahweh speaks only through Moses.

Graetz's (2001) question, 'Why was Miriam punished and not Aaron?' and her response to it perhaps covers all those questions and exposes the heart of the matter here:

I suggest that Miriam was punished with leprosy because women in the biblical world were not supposed to be leaders of men, and that women with initiative were reproved when they asserted themselves with the only weapon they had, their power of language: a power which could be used viciously and was, therefore, called lason hara, literally the evil tongue. (pp. 232-233, 233ff., [author's own italics] $)^{4}$

The 'rogue prophets' episode interrupts, but does not override, the story of the first rebellion, which is picked up again in verse 31 . That episode ends in tragedy. But as I see it the point is not so much the punishment meted out to those

4. It is not necessary here to indulge in the many ways the rabbis sought to denigrate Miriam because of her temerity to challenge Moses: slander, evil, malicious gossip, Miriam because of her temerity to challenge Moses: slander, evil, malicious gossip, jealousy. Graetz does an excellent job of exposing and refuting this reasoning. She does not infer that Miriam was indeed using the power of language 'viciously', but shows that the rabbis linked the 'evil tongue to women's speech, and in this case specifically Miriam. Ironically, the attention paid to her shows the power of he presence and words. who rebelled even though in itself it does stun the mind. The point here is the cool, calculated, deliberate premeditation of it, and the shock and awe with which it is executed. Between 11:16 and 11:23 Yahweh and Moses concoct not just the plan of the election of the 70, but also a way to punish the rebellious. The plan is to invite the people to a ritual feast for which they must 'consecrate' themselves (v. 18) - a 'preparation for a solemn religious occasion' Maarsingh calls it. It was to be a 'dinner' that would last 'a full month and God himself would provide an abundance of meat' (Maarsingh 1987:40). Even though the story provides hints of something sinister afoot - they will eat meat until 'it comes out of their nostrils' - the plan itself remains a secret between Moses and Yahweh.

There is a lengthy conversation about the availability of the meat the rebels craved and which should be ready for the feast, told in a way that leads up to Moses' having to be convinced of the power of God to provide so much meat. Moses pointedly reminds Yahweh of the numbers: 'six hundred thousand on

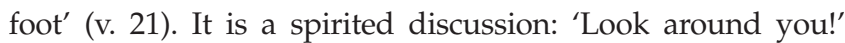
Moses seems to say. He does not see enough flocks and herds to slaughter. Carried away by the heat of the moment, Moses asks, 'Is there even enough fish in the sea?' - an amazing question to ask in the desert (v. 22). 'Is the LORD's power limited?' God retorts, putting an end to the argument (v. 23). Does Moses not suspect anything, or is he simply anxious that Yahweh might be underestimating the logistics involved?

As the story continues in verse 31 , three things become very clear: One, the invitation to a feast turns out to be an act of premeditated deceit. There really is no other way to put it. The people seemed to have been lured with deceitful promises: they will have a feast lasting 'a whole month'. Instead, they have 'consecrated' themselves for a feast of death. Two, the unlimited power of the LORD was after all not the power to mercifully provide; it was the power to mercilessly destroy. Three, the act is both ritual (a feast for which they must be consecrated), and political - this becomes a lesson, not only in the power and glory of God, but also in the untouchability of Moses' rule. As the narrative has it, the God who comes to Moses' defence is utterly ruthless. The terror inflicted upon those who challenged Moses will be a lesson to all. It goes precisely as the divine plan intended. The people sat down to eat, and would not stop. But if this were meant as divine punishment, could they even stop? They gorge themselves on the quails. In a horrific scene, through nausea, choking and vomiting, they die 'while the meat was still in their teeth'. With the fresh mass graves behind them, the survivors journeyed from this place of destruction to Hazeroth. They leave the many dead bodies behind them, but they will carry the reality of the wrath of the God of Moses with them.

But are the terrorised now cowed into submission? While others might be, Miriam clearly is not.

'The rabbis wonder why the Hebrew word for "spoke" wattedabber is in singular form rather than wayyedabberu, in plural form', because the text says that Miriam and Aaron 
spoke. Why does Miriam, they ask, a woman, precede Aaron because 'ladies first was not a principle in ancient times?' (Graetz 2001:231). It is an issue because it is clear that it is Miriam who takes the initiative. She is providing leadership, and it is a sin that will not be easily forgiven.

Miriam's act comes as a crucial intervention in the rebellion. In reality, it has the effect of a paradigm shift in the rebellion from trivialities to matters of fundamental importance, and from male leadership to female leadership. Miriam introduces the real issues: of the people's participation in liberation, the quality and integrity of leadership and the questions of power and authority. She raises matters she has given leadership in before, at the seashore: the legitimacy of the radical inclusion of all the people, male and female, in God's acts of liberation. Instead of speaking under a pretext of less important matters, Miriam's question goes to the root of the matter - Moses' increasingly autocratic, and increasingly unpopular, rule. Miriam's critical question also exposes a basic fault line in the rebellion: the nostalgic yearning for Egypt, the longing for the non-existent kindness of the oppressor, the desire to return to the imagined safety of Mitsra'im instead of facing the hardships that come with freedom.

And still it is about more. A world of meaning rests on the question, 'Has the LORD spoken only to Moses?' Up till now, the storyteller has taken great pains to ensure that we understand that Moses, and Moses alone, is God's chosen instrument. Also, it is never Moses on his own who makes decisions, but Moses and God, a God who boils in anger when Moses' authority is being challenged. And when God's anger flares up on behalf of Moses, the punishment is swift and severe as we have seen with the fire and the 'feast' of quails. Miriam's question is not only about the channel of God's voice. It is about the character of Israel's God. Who is this God Moses claims to be on his side, who gives him sole authority, who punishes and strikes and kills at the slightest sign of challenge and protest?

In the acts of defiance of the midwives and on the riverbank Miriam experienced a God who rises up in outrage against the violence and death-worshipping power of the empire. At the seashore, Miriam, in contrast with Moses, proclaimed faith in a God not in need of violence, of horses, armies and chariots. Now Miriam is saying that Moses' God is not the God she remembers from the tradition of the women. The God of Moses is a power-hungry, vengeful God, a frightening mirror image of the gods of Egypt who know only domination, submission and death. Moses' God has taken on fearsome, terrifying proportions.

Self-described atheist Richard Dawkins (2008) offers a shocking description of what he calls the God of the Old Testament':

The God of the Old Testament is arguably the most unpleasant character in all fiction: jealous and proud of it; a petty, unjust, unforgiving control freak; a vindictive, bloodthirsty ethnic cleanser; a misogynistic, homophobic, racist, infanticidal, genocidal, filicidal, pestilential, megalomaniacal, sadomasochistic, capriciously malevolent bully. (p. 51)
As far as it goes, Dawkins is not making this up. However, this is not 'the God of the Old Testament'. As we are discovering, the picture is much more complex than Dawkins might be willing to allow. It is, however, despite our feelings of discomfort, a not completely inaccurate description of the God in the narrative whom Moses claims as the God who has appointed him, and who is now leading Israel's people to the Promised Land - Moses' personal benefactor and the fierce protector of his rule. It is the God Miriam rejects. Is the God who 'speaks only through Moses' indeed the God we have come to know? It is, emphatically, not the God of the birthing stool, the riverbank or the seashore. And at heart, Miriam's quarrel with Moses has to do with the fundamental question: which God are we talking about and calling upon here? It is the question persistently raised by the women who walk in Miriam's footsteps, determined to keep the prophetic tradition alive: Hannah in her song (I Sm 2); Mary in the Magnificat (Lk 1: 46-56); the Syro-Phoenician woman in her persistence (Mt 15:21-28); and Martha in her bold confession (Jn 11:27). It is the question raised by people oppressed by empires, invaders and colonisers everywhere who seek justification for their imperial designs in the Bible.

'If one reads the Bible carefully', Graetz writes, 'there are enough hints that Moses' distancing himself from the people may ultimately have been the cause of his downfall' (2001:238). Despite Graetz's gentle phrasing - Moses' 'distancing himself' - it is undeniable that Moses' style of governing was costing him serious support among the people, to the extent that it caused his 'downfall' ( $\mathrm{Nm} 20$ ). Miriam's speaking up, significantly, comes immediately after the incomprehensible punishment Yahweh metes out against those 'who had the craving' for meat and hence complained bitterly to Moses, that is, against his leadership, and, so the passage lets us understand, in effect against God. It was the LORD who became 'very angry', but Moses was no less 'displeased' (11:10). The two of them worked in tandem and plotted a plan that has all the hallmarks of a set-up. Chapter 11:31-35 is almost too painful to read.

But this is what happens when authoritarian rule, secure in the belief of its 'manifest destiny', the certitude of its exceptionalism and the blessing of God, is challenged. Miriam is therefore much more radical than the men who hid the anxiety about Moses' leadership behind complaints about food and yearnings for Egypt. For her, it is not the stomach and comfort that is at stake: at stake is the ultimate question: if Moses calls upon God, whose God, which God, is that? And if that is our God, what kind of liberation are we speaking of here?

Miriam is challenging an idea that has taken hold because the appropriation of the exodus story after the passage through the Red Sea and is now solidifying into a stringent, exclusivist, religious ideology: that Yahweh now only mediates, speaks and guides through men. And it is a concentrated, jealously guarded transferral of power from a male god to the males in Israel, and the guarantee of an exclusive, male relationship between Yahweh and men in which women have no place, 
standing or status except in the shadow of, and subservient to, the men. It is a distortion of the God who blessed the midwives when they turned their powerlessness into acts of liberatory courage without the permission or support of the men, and of the God who inspired Miriam to stand her ground at the riverbank and to prophesy at the seashore, showing what it means to be a leader of all the people. Now Miriam rises up against this ideology and this ideologised God.

This episode is bracketed by Moses' remarkable rejection of rebuke for the male prophets, his even more remarkable wish for 'all the LORD's people' to become prophets, and Miriam's speaking. Most commentaries see this as a serious transgression. The rabbis call it 'arrogance' and 'slander', because she speaks against someone 'greater than herself' (Graetz 2001:237). This is Miriam's grave sin, 'worse than rape and equal to murder' (Graetz 2001:239). And indeed these are dangerous, rebellious and if read within the context of the ongoing conflict about leadership, subversive words: 'Has the LORD spoken only through Moses? Has he not spoken through us also?' (11:2). If read within the context of the people's growing dissatisfaction with authoritarian rule and cosmetic reform (the 70), and most important of all, if we understand Miriam's question to be a prophetic, theological challenge, then Miriam's words are not petulant jealousy, slander or arrogance, but prophetic truth spoken to power.

Indeed she has already been called a prophet (Ex 15:20). Now she picks up that mantle again, re-asserting herself in her calling by inserting herself into the rebellion, but correcting the rebellion from its flawed position (romanticising Egypt and anger about bodily comforts) to fundamental revolutionary transformation of leadership and the theological integrity of the call upon God. But the circumstances have changed. The euphoria of the exodus, the wonders at the Red Sea, the drowning of the armies of Pharaoh, his horses and his chariots are challenged by the hardships of freedom. Now it is not Pharaoh's armies the Israelites are seeing on the sea shore, it is the bodies of their kin, slain by Yahweh in collusion with their leader, and left in the graves of craving at Kibroth-hattaavah. The revolution is eating its own children. That jubilation of freedom at the sea that could embrace the prophetic leadership of Miriam has perished in the Realpolitik of the wilderness. And Miriam does not wait. It was 'while they were [still] at Hazeroth' that she spoke up.

Miriam speaks prophetic truth to power and it is so serious that not Moses responds to this, but Yahweh intervenes directly in defence of Moses. And this is perhaps the answer to Graetz's last question: 'Did Miriam and Aaron pose a real threat to Moses?' (2001:232). The matter is serious indeed and for all intents and purposes Aaron does not really count here. It is Miriam who speaks and refocuses the rebellion. Up till now, the people's rebellion was a rebellion about food. What Israel now wanted was what they, in their desperation, imagined they had in Egypt: food 'for nothing' (11:5). Forgotten are the chains, the crushing humiliations and the severe hardships. Forgotten also is the truth that they paid for this for with their bodies, their hopes, their dignity and the lives of their children. They cannot distinguish between free food in slavery and hardship in the struggle for freedom.

Miriam's intervention not only corrects their priorities, but it also reshapes their imagination. A revolution is not won by recasting the past into an imagined, and false, generosity of the oppressor who gives you food because he needs your physical strength for slave labour. A revolution is won by imagining, and shaping a different future, by understanding that hardship in the wilderness is hardship on the way to that alternative future. It is the difference between the delusionary imagination and what Walter Brueggemann calls 'the prophetic imagination'. This is an imagination that 'embrace[s] the very imagination of God' and that means that it not only knows that things could be different, 'but that the difference could be enacted' (Brueggemann 2001:xxi, [author's own italics]). And this is what Miriam's prophetic imagination does. Miriam refocuses the rebellion on the questions of the character of the God of liberation, the quality of leadership, of power and powerlessness, and the difference between power and authority.

In becoming more and more authoritarian, holding fiercely onto the power of prophecy for himself alone, more and more intolerant of criticism and correction, Moses, knowing he has no argument in himself (Yahweh has indeed not only spoken through him alone), more and more falls back on his own, unique relationship with God, calling upon a despotic Higher Power who works only on his behalf. Miriam has spoken, not just against Moses, but against his claim that his way was God's way. That is not insolently challenging a younger brother who has done better. Rather, it is challenging a religious ideology bent on maintaining a male hierarchy, a revisionist, male version of the history of liberation and a male god on the side of male dominance and the constant threat of violence hanging over the smallest sign of dissent.

What Miriam represents is a yearning on the side of the people for that other history to be reclaimed; that history in which the women - the midwives, her mother and she herself - claimed legitimate and revered space in the story of liberation. What she represents is the longing for the God of liberation who takes the side of the oppressed and the weak, the marginalised and the excluded, the radically inclusive God who gave strength to the women in their defiance of the power of Pharaoh when there was no male Israelite in sight: not in the birth chamber and not on the riverbank. This is taking the rebellion to a totally different level. It is no wonder the narrator cannot let Moses handle this alone. He calls in Yahweh - the same God who has just shown a fierce partiality for Moses and male leadership in Israel by brutal suppression of a rebellion merely about food. Miriam knew this. She must have known this. And yet, like her fore-mothers in Egypt, despite the risks, she speaks.

The ominous words in 12:5, 'and The LORD heard', now take shape in the form that appears in the doorway of the tent, summoning Moses, Aaron and Miriam. The narrator makes sure we see and understand it immediately. In verse 1 , in the act of rebellion, Miriam was named first. Now in the act of 
retribution, she is already diminished. She is named last, set lower and set aside - for punishment. Her life is saved by the two males in the story. The proper order of things is restored. Aaron, unpunished and his priesthood left intact, but clearly brought to heel, appeals to Moses - not to God, so great is his awe of Moses' power now - 'Oh my lord! Do not punish us for a sin that we have so foolishly committed!' (12:11). And Moses appeals to God. Of an independent relationship between Yahweh and Miriam, there is now no sign. The Spirit that had enveloped her on the riverbank and at the seashore is now crushed by the men and their God. She must either forget it ever happened, or accept the lie that it never happened. It was all a figment of a petty, jealous, female mind.

She is put in her place, not by Moses but by his God. In the two most ominous, and revealing, sentences of this pericope, God asks Miriam, 'Why were you not then afraid to speak against my servant Moses?' (v. 5). We should absorb this: It is not love or faith and trust in Yahweh she needs, it is fear of Moses - of men, in other words - that pleases this God. And as she is punished, God, still angry, responds to Moses' plea for her healing, 'If her father had but spit her in her face ...' (v. 14). No longer a prophet or leader, she is reduced to some father's daughter. There are sobering lessons to be learnt here. God heals, but only grudgingly. But second, so goes the sanctification of patriarchal violence. Every patriarchal father is justified in his anger at an impudent daughter, and every woman who does not know her place will know that being spat in the face is actually an act of mercy and generosity of spirit. She should be grateful - it could have been worse. A man can, and is allowed, to do so much more. She will have reason to be afraid.

But even here the patriarchal text cannot suppress the truth completely. As Miriam is banished 'outside the camp' until her leprosy is healed, the people refuse to journey on without her. Such was her stature, and their trust in her. Again Trible (2001) eloquently captures the situation:

Those whom she has served do not forsake her in the time of her tribulation. They wait. Never do they assail her as on various occasions they attack Aaron, Moses, and God. And their allegiance survives unto her death. (p. 180)

The feminist scholars are right: there is a whole other narrative, a whole other tradition we are not being told here.

\section{The waters of Meribah}

Three references in Num. 20:1 - 'the people of Israel', 'the whole community', and 'the people' - emphasize their presence when she dies and is buried in Kadesh. The steadfast devotion of the people to Miriam indicates a story different from the regnant one. (Trible 2001:180)

Yet it flares up every now and then. 'Patriarchal storytellers', writes Trible, 'have done their work well. They have suppressed the women - yet without total success' (2001:169). The seashore is such a moment, and here we have it again. Miriam's death is mentioned in Numbers 20:1, and in only seven words. We have to wonder: such a life and only seven words? We are told that the water in the well suddenly dried up. It is never explained why. Verse 2 merely reports that 'there was no water for the congregation'. But are the dried up waters of Meribah, before it became yet another, and for Moses, the final place of contestation, a silent cry of inexpressible mourning at the passing of this amazing woman, without whose prophetic leadership the people will now have to face the future, and simultaneously a rallying cry for all those who embrace the prophetic tradition of Miriam?

Numbers chapter 20 also tells us about the final rebellion which called forth the 'sin' of Moses. Miriam dies and there is no water. The people rebel. 'Why have you brought us up out of Egypt?' (v. 5). Maarsingh's translation is enlightening: 'Why did you deceive us with a promise of a land situated on a higher plane?' Canaan does indeed have a higher elevation, Maarsingh explains (1987:71), hence the 'up' from Egypt. But perhaps this is more than just about geography. Can we read in this expectation of a 'higher plane' also the promise of a higher level of leadership than what the people experienced from Pharaoh, his priests, his nobility and his slave drivers in Egypt? More integrity, more decency, more inclusivity, more love, more reflective of the God of the exodus than Moses' God of the wilderness turned out to be; an elevated leadership of the kind Miriam called for?

The story here reads as if Moses experienced this as a final straw. He does indeed consult God, and God does indeed respond, but this time with genuine concern for the wellbeing of the people, without any accompanying threat of vengefulness because of their complaints, seemingly surprising Moses totally. Moses shall simply speak to the rock and water shall flow. Moses, however, is angry; his disdain shows in his words and in his deeds. 'Listen you rebels!' he says to the people. Now they are no longer God's children whom God must tenderly nurse and nurture (Nm 11). Now also, there is no distinction between 'the people' and 'the rabble' who instigate them to disobedience. Now they are all 'rebels'. Notably, there is no more Miriam to take the lead in the rebellion and to expose the real character of his leadership and the falseness of his claims upon the God of liberation. But Moses is angered, perhaps because even though Miriam is dead and gone, her subversive memory, her challenge to leadership and her dangerous ideal of prophetic leadership still linger.

So now the narrator allows what up to now had seemed impossible: Moses sins, and that sin is so great that it turns his God against him. Moses 'strikes' the rock instead of simply speaking to it, as Yahweh commanded. Scholars have battled extensively as to what is happening here and what precisely Moses' ' $\sin ^{\prime}$ is. ${ }^{5}$ Biblical scholars are agreed that Numbers 20:2-13 indeed tells us about a rebellion in response to which Moses and Aaron, as Maarsingh puts it, 'failed to show [the people] the reflected image of God' (p. 72). Moses'

5.Budd (1984:218-219) provides extensive references to these debates 
response is 'arrogant', claiming that he and Aaron 'had the power to provide the water' (Budd 1984:218-219). In the end (Nm 20:24; 27:14), the author, with supreme irony, accuses Moses and Aaron of 'rebellion'.

Pinchas Kahn argues for 'psychological transference' by which he means that Moses transferred the experience of Rephidim in Exodus 17 where there was a rebellion against Moses, to Meribah, where there was no rebellion (Kahn 2007:85-93). Accordingly, Moses completely misjudges the situation. The people were not complaining, or longing for Egypt, but were distressed that they were still in the desert rather than in the Promised Land. 'Moses ... may have misunderstood them, displaying here a transference from the past experience at Rephidim to the present one at Waters of Meribah' (Kahn 2007:87). In the process Moses erred on three counts: one, he mistook the people's longing for the Promised Land for a 'rebellion'. Two, he misunderstood his own position: at Rephidim, his authority needed to be enhanced. Here at Meribah, it was 'necessary to diminish' that authority. 'That Moses did not understand this necessity was his error, perhaps his sin' (Kahn 2007:89). Three, Moses and Aaron responded to their own emotional urge, rather than to the needs of the people. All of this comes down to one reality: 'they indicated that they were no longer able to be the people's leaders' (Kahn 2007:92). But Kahn does not explain why there is this sudden 'necessity'. We have argued that the issue of leadership is not a sudden crisis at all. It has been building up since chapter 11, and that it is about much more than a mistake caused by 'emotional transference'.

Moses is instructed to 'take up his staff', and this too has caused some controversy (Budd 1984:218). Taking up the staff here is reminiscent of his staff before Pharaoh, and at the parting of the Red Sea. But that is a reminder not of situations focused on Moses' power, but where the power of Yahweh is everything. The staff is not a symbol of Moses' power but rather of trust and faith in the unerring love of Yahweh who will secure Israel in justice and peace. Before Pharaoh Moses cannot even speak properly, and at the Red Sea he knows to remind the people of the power of Yahweh: 'The LORD shall fight for you'. Taking up this staff, Moses should have known. This is probably closer to Moses' real misunderstanding of the situation. It becomes the turning point.

We may raise other questions: Is Moses so wedded to acts of violence to prove and secure his authority, and so used to the God who strengthens him in this expectation, that he cannot believe it when he hears God say something else completely? And is, at this stage, his confidence in himself, without the violence, so shaky that he willy-nilly clings to what he believes to be the only way that has worked before? Maarsingh remarks that the Targum Pseudo-Jonathan 'shares the curious information that the first time [when Moses struck the rock] drops of blood appeared'. Perhaps the authors of Targum PseudoJonathan knew better how to metaphorise the hold violence exerts on those who depend on it for strength (1987:72). Can Moses conceive of leadership without fear, intimidation and the threat of violent suppression? How else would he impress the people and reassert his leadership? Deeper perhaps: can Moses conceive of Yahweh only as vain, violent and vengeful? Whatever happened here, Moses ignores Yahweh's command to let only his words be his power and his authority.

Moses' conundrum is the conundrum of every struggle for freedom: a revolution without vengeance, a struggle without the fear-inducing discipline of violence and the promise of retribution - is that a revolution worthy of the name? If violence is the bedrock of our struggle credentials, how shall we claim victory without it? If liberation is nothing without conquest, the God of the exodus must give way to a god of conquest. If freedom is unthinkable without conquest and occupation, a compassionate God of love and tenderness is a God too effeminate for the struggle in the wilderness. Moses does not believe that God does not need the violent act in order to be God. But Moses needs a violent God in order to be Moses. Because he cannot speak to the 'rabble', he will not speak to the rock. Because Yahweh refuses to strike the people, Moses strikes the rock.

Is this perhaps a belated realisation by this narrator that the God of Israel is, after all, Miriam's God? Numbers 20:2-13 is a narrative critical of Moses and Aaron, says Trible. 'In effect, [it] counters the vendetta against her' (Trible 2007:181). So this is not just about Moses. It is also about Yahweh. The God at the waters of Meribah is not the same as the God of the fire, the feast of death, the swallowing earth and the plague. Here Moses' God does not come to his aid: not in anger to smite the rebels, not in vengeful defence of Moses and his leadership and not in tenderness to comfort Moses. The God that Moses had come to count on forsakes him. In the end, the voice of Yahweh is heard, not in wrath or retribution or the arrogance of violence, but in the creative, life-giving word. It is the God that Miriam worshipped in song and jubilation at the seashore. And as the God of Miriam is recalled, the waters of Meribah becomes a life-giving source.

\section{Outside the camp}

Trible speaks of 'fragments of a pro-Miriamic tradition' that come to the surface despite centuries-long efforts to suppress it. The prophet Micah reclaims her and names her in one breath with Moses and Aaron, making her their equal. For Trible, women - from Deborah (Jdg 5) to the unnamed woman in Isaiah 8:3, to Hulda (II Ki 22:14-20), and Noadiah (Neh 6:14) - each of them witness 'to a heritage rooted in Miriam'. Trible (2001:181-182) concludes, 'If Moses be the archetype of the male prophetic tradition, Miriam leads the female' (Trible 2001:181-182; cf. Kessler 2001:85-86). ${ }^{6}$

But I have argued here that humanly speaking (Boesak 2015:162-167), ${ }^{7}$ the prophetic tradition in the Bible is the

6.In this regard, I agree with Rainer Kessler, however, who argues, in my view convincingly that Miriam is the female who represents prophecy, but not a 'female convincin' tradition'. The female prophets in Israel 'are not reduced to a special female field in prophecy, but represents, as Miriam doe $01: 85,86$

7.See my argument on the story of the tower of Babel as the story of God as the original voice of dissent against the powers of empire (see Boesak 2015:162-167). 
tradition that begins with the midwives in Exodus 1. Miriam takes it forward. Miriam is not called a prophet because of any 'prophecies' she uttered, of which we find none. She is a prophet because of the tradition she represents and preserves. She is a prophet not because she foresees the future, whatever that may mean. She is a prophet because she sees what, and as, God sees: through the eyes of the oppressed, the despised, the outcasts, the ravaged, the powerless and those who suffer.

It is a tradition that calls upon God as the God of slaves, the One who takes the side of the oppressed in their struggles for freedom and justice against the tyranny of oppressors and the domination of empire. This is a God fundamentally different from, and fundamentally in opposition to the gods of empire, who depend on subjugation, the suppression of all dissent, violence and the threat of destruction. This God is a God of life-giving hope, whose acts of liberation are acts of radical love, radical inclusivity, radical freedom and radical resistance. This is that tradition Miriam claims on the riverbank, at the seashore and in the wilderness. It is the tradition that worships God as the God of the poor and oppressed, of justice and peace as that God is proclaimed in the most radical proclamations of that tradition throughout ancient Israel's history: the tradition in which Jesus of Nazareth plants himself.

This is the tradition rooted in the acts of defiance against empire by Siphra and Puah stand Miriam on the riverbank, at the seashore and in the wilderness, Hannah and the prophetic power of her Song (1 Sm 2), Rizpah in her resistance against King David and the palace establishment (2 Sm 21:14-22) (footnote, Radical Reconciliation, chapter 2), Mary in the Magnificat and Jesus of Nazareth. It is the tradition that the 'radical Paul' as John Dominic Crossan calls him, will follow in his insistence on the supremacy of the Lordship of Jesus over against the claims of Roman imperial theology, and his theology of freedom, justice and equality as expounded in his letters (Crossan 2007:143-190). The 'male, Moses tradition', as we have seen, is seduced by the needs of patriarchy and the desire to imitate the ways of empire in Israel. It is against that tradition that the Miriamic tradition struggles, and survives.

Trible (2001:181) sees the last reference to Miriam in the book of Micah. But perhaps it is helpful to see Hebrews 13:13 as a final reference not just to Jesus, but to Miriam. 'Let us then go to him outside the camp and bear the abuse he endured'. Even though this is a text we are used to reading within the context of a theology of atonement and the 'satisfaction theory' - God punishing Jesus for the sake of our sins - this is nonetheless not the point of the text. The text is an invitation, not for us to, like Jesus, take upon ourselves the sins of the world and seek God's satisfaction through the shedding of blood - after all, who can possibly do that, and more pertinently, does God really want that? The invitation to the disciples of Jesus is to join him in his suffering of shame, rejection and abuse.

Hebrews 13:3 is the only place in the New Testament where the words 'outside the camp' are used. In Numbers 12, Miriam is punished and condemned to life outside the camp until she is cleansed. There, the people refuse to journey on without her as a sign of their solidarity with her and their desire not to move on unless she is restored to their midst (Trible 2001:180). In Hebrews, the Miriam punishment is recalled. The New Testament describes Jesus as the oppressed One who came to liberate and bring justice to the poor, the hungry, the naked, the widows and orphans, the oppressed and the afflicted; those who cannot defend themselves against the powerful. This is how he announces himself (Lk $4: 16-18)$, and this is how he reveals himself in his work on earth and in the experience of oppressed people. So James Cone (1972) writes:

Jesus Christ is not a proposition, not a theological concept which exists merely in our heads. He is an event of liberation, a happening in the lives of oppressed people struggling for political freedom. Therefore, to know him is to encounter him in the history of the weak and the helpless. The convergence of Jesus Christ and the black experience is the meaning of the Incarnation. (pp. 32-33)

That encounter takes place in the places of revilement, oppression and abuse, outside the camp. Jesus is, as Andries van Aarde forcefully and persuasively argues, 'fatherless in Galilee' bearing all the rejection, exclusion and shame such a reality, being 'fatherless' and 'from Galilee', carries with them (2001). He is the oppressed one, bearing the shame and abuse for our sake, in other words, becoming one with the shamed and abused, the despised and rejected, joining their struggles against the powers represented by the Temple elites, the palace of Herod with its murderous subservience to Rome and the Roman Empire itself. It is that identification, solidarity and resistance which place him 'outside the camp'. To be 'outside the camp' is to be 'against the camp' and all it stands for.

Moreover, here in Hebrews, we are not asked to wait until he is cleansed so he can return to the camp. The despised ones were cast outside the gate and outside the camp because the supposition was that inside the camp was the sacred space, where God dwelt, where sanctification was to be found (Lane 1991:543). Their presence defiled that sacred space. Hebrews turns that around: the sacred space is outside the camp, for that is where Jesus is always to be found - among the withered orphans and wailing widows of Yemen, the bewildered refugees from Syria, the despised and targeted LGBTQI persons from every community on earth, the oppressed and excluded women who dare to claim the dignity God has given them. It is there, outside the camp, where they, as Bonhoeffer (2012) reminds us, will hear the voice of Jesus:

You outcasts, you disadvantaged ... you who are looked down upon ... Blessed are you Lazaruses of all ages, you broken down and ruined, you lonely and abandoned, those who suffer injustice, you who suffer in body and soul; blessed are you for God's joy will come over you and be over [your] head forever. That is the gospel, the good news. (pp. 446, 447)

The despised space becomes the sacred space, sanctified by suffering and the presence of Jesus. That is where the good news will be heard. 
We are not asked to wait until he is 'restored' by the powers and allowed to continue the journey with us. The invitation is much more radical. We are invited to journey with him. We are invited to go to him, knowingly, willingly and determinedly, not only because it is there that he is to be found, but because that is where we belong. The invitation, not just to 'bear the cross' with him, but to be crucified like him for the sake of those who are crucified daily by the forces of empire - from Palestine to Yemen to Soweto to the bloodstreaked streets of America's inner cities - is an open one, for as long as Gods' children are despised, cast off and excluded, thrown out of the camp, trampled upon and crucified, that is where Jesus will be found. That is where black liberation theology finds its meaning, in the company of Miriam and Jesus, taking their stand with the wretched of the earth.

\section{Acknowledgements Competing interests}

The author declares that he has no financial or personal relationships which may have inappropriately influenced him in writing this article.

\section{References}

Boesak, A.A., [1987] 2015, Comfort and protest, the apocalypse of John from a South African perspective, Wipf and Stock, Eugene, OR.

Boesak, A.A., 2004, The fire within, sermons from the edge of exile, Aardvark Press, Cape Town; 2007, Wild Goose Publications, Glasgow.

Boesak, A.A., 2015, Kairos, crisis, and global apartheid, the challenge for prophetic resistance, Palgrave MacMillan, New York.

Bonhoeffer, D., 2012, Dietrich Bonhoeffer works English, 11, Fortress Press, Minneapolis, MN.

Brown Douglas, K., 2015, Stand your ground: Black bodies and the Justice of God, Orbis Books, Maryknoll, NY.

Brueggemann, W., 2001, The prophetic imagination, 2nd edn, Fortress Press, Minneapolis, MN.

Budd, P., 1984, Numbers, Word Biblical Commentary, Word Books, Waco, TX.

Calvin, J., 1981, Commentaries, vols. I, III, IV, (Old Testament); and Vol. I, (New Testament), Baker Books, Grand Rapids, MI.

Cone, J., 1972, God of the oppressed, Orbis Books, Maryknoll, NY.
Crossan, J.D., 2007, God \& empire, against Rome, then and now, HarperOne, San Francisco, CA.

Dawkins, R., 2008, The god delusion, Mariner Books, Boston, MA.

Durham, J.I., 1987, Exodus, Word Biblical Commentary, Word Books, Dallas, TX.

Exum, J.C., 2001, 'Second thoughts about secondary characters: Women in exodus', in A. Brenner (ed.), Feminist companion to exodus to Deuteronomy, pp. 75-87, Sheffield Academic Press, Sheffield.

Fretheim, T., 1991, Exodus: Interpretation, a commentary for teaching and preaching, Westminster John Knox Press, Louisville KY.

Friedman, R.E., 2003, The Bible, with sources revealed, a new view into the five books of Moses, Harper, San Francisco, CA.

Graetz, N., 2001, 'Did Miriam talk too much?', in A. Brenner (ed.), A feminist companion to exodus to Deuteronomy, pp. 231-242, Sheffield Academic Press, Sheffield.

Jacob, B., 1992, The second book of the bible, exodus, transl. W. Jacob, KTAV Publishing House, Hoboken NJ.

Jansen, J.G., 2001, 'Song of Moses, Song of Miriam: Who seconded whom?', in A. Brenner (ed.), A feminist companion to exodus to Deuteronomy, pp. 187-199, Sheffield Academic Press, Sheffield.

Jost, R., 2001, 'The daughters of your people shall prophesy', in A. Brenner (ed.) Prophets and Daniel: A feminist companion to the bible, pp. 70-76, Sheffield Academic Press, (Continuum), New York.

Kahn, P., 2007, 'Moses at the waters of Meribah - A case of transference', Jewish Bible Quarterly 35(2), 85-93.

Keil, C.F. \& Delitzsch, F., n.d., Biblical commentary on the Old Testament, vol. I, The Pentateuch, transl. J. Martin, Eerdmans, Grand Rapids, MI.

Kessler, R., 2001, 'Miriam and the prophecy of the Persian period', in A. Brenner (ed.) Prophets and Daniel: A feminist companion to the bible, pp. 77-86, Sheffield Academic Press, (Continuum), New York.

King, M.L., Jr., [1963] 1981, Strength to love, Fortress Press, Philadelphia, PA.

Lane, W., 1991, Hebrews, Word Biblical Commentary, Word Books, Dallas, TX.

Lind, M.C., 1980, Yahweh is a warrior, Herald Press, Scottdale, PA.

Maarsingh, B., 1987, Numbers: A practical commentary, text and interpretation, Eerdmans Publishing Company, Grand Rapids, MI.

O'Donnel Setel, D., 1998, Exodus, C.A. Newsom \& S.H. Ringe (eds.), Westminster John Knox Press, Louisville, KY.

Potgieter, C. \& Nadar, S., 2000, 'Living it out: Liberated through submission? The worthy woman's conference as a case study of formenism', Journal of Feminist Studies in Religion 26, 141-151.

Siebert-Hommes, J., [1994] 2001, 'But if she be a daughter ... She may live', in A. Brenner (ed.), A feminist companion to exodus to Deuteronomy, pp. 62-74, Sheffield Academic Press, Sheffield.

Trible, P., 2001, 'Bringing Miriam out of the shadows', in A. Brenner (ed.), A feminist companion to exodus and Deuteronomy, pp. 166-186, Sheffield Academic Press, Sheffield.

Van Aarde, A., 2001, Fatherless in Galilee, Jesus as child of God, Trinity International Press, Harrisburg.

Zuurmond, R., 1976, Het Bijbelse Verhaal: Verteller en Vertaler, Mededelingen van de Van der Leeuw Stichting, 41, Private Collection, Amsterdam, p. 2511. 